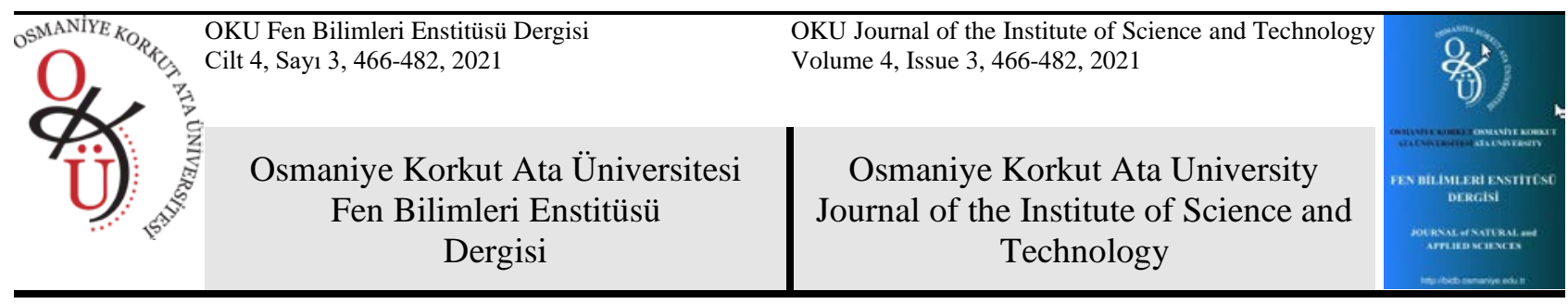

Quantification of the Impact of Land Use/Land Cover Changes on Ecosystem Services: A Case Study in Adana-Karaisalı

\author{
Gülay TOKGÖZ ${ }^{1 *}$, Nuriye SAY ${ }^{2}$ \\ ${ }^{1}$ Iskenderun Technical University Faculty of Architecture, Department of Landscape Architecture, 31200, Hatay \\ ${ }^{2}$ Çukurova University, Faculty of Architecture, Department of Lanscape Architecture, 01330, Adana
}

${ }^{1}$ https://orcid.org/0000-0002-9527-9379

${ }^{2}$ https://orcid.org/0000-0003-2556-2002

*Sorumlu yazar: gulay.tokgoz@iste.edu.tr

\begin{tabular}{|c|c|}
\hline Research Article & ABSTRACT \\
\hline $\begin{array}{l}\text { Keywords: } \\
\text { Ecosystem services } \\
\text { Land use and land cover } \\
\text { NDVI } \\
\text { Ecosystem services valuation }\end{array}$ & $\begin{array}{l}\text { Global scale changes in land use affect biodiversity, global climate, and ecosystem } \\
\text { services. Integrating a local and regional ecosystem service approach into plans and } \\
\text { policies levels is essential for sustainable land management. In this study, land } \\
\text { use/land cover differences in Adana-Karaisali district of Turkey were investigated } \\
\text { using Normalized Difference Vegetation Index (NDVI). Landsat satellite images } \\
\text { of the area from } 2000 \text { and } 2016 \text { were analyzed using ISODATA method and } 16 \text { land } \\
\text { use were identified based on the third level of the CORINE classification } \\
\text { framework. The results showed that the biggest changes occurred in agricultural } \\
\text { areas, } 2.57 \% \text { decrease in non-irrigated arable land while a } 7.14 \% \text { increase was } \\
\text { observed in permanently irrigated lands. In spite of the decrease in the number of } \\
\text { inhabitants in the area, continuous urban fabric increased at the rate of } 0.07 \% \text { and } \\
7.62 \% \text { increase was observed in forest lands. The positive or negative effects of the } \\
\text { identified changes on ecosystem services based on the Common International } \\
\text { Classification of Ecosystem Services (CICES) framework were evaluated. In the } \\
\text { case of Karaisal, in spite of the decrease in water bodies and natural landscapes, it } \\
\text { has been observed that increases in agricultural areas, forests, and artificial surfaces } \\
\text { positively have affected ecosystem services valuation in the district. }\end{array}$ \\
\hline
\end{tabular}

Arazi Kullanımı/Arazi Örtüsü Değişikliklerinin Ekosistem Hizmetleri Üzerindeki Etkisinin
Sayısallaştırılması: Adana-Karaisalı Örneği

\section{Araștırma Makalesi}

Makale Tarihçesi:

Geliş tarihi: 30.09.2021

Kabul tarihi:23.10.2021

Online Yayınlanma:15.12.2021

\section{Anahtar Kelimeler:}

Ekosistem hizmetleri

Arazi kullanımı ve arazi örtüsü

NDVI

Ekosistem hizmetleri değerleme

\title{
ÖZET
}

Arazi kullanımındaki küresel ölçekteki değişiklikler biyolojik çeşitliliği, küresel iklimi ve ekosistem hizmetlerini etkiler. Plan ve politikalara yerel ve bölgesel bir ekosistem hizmeti yaklaşımının entegre edilmesi, sürdürülebilir arazi yönetimi için esastır. Bu çalışmada, Türkiye'nin Adana-Karaisalı ilçesindeki arazi kullanımı/arazi örtüsü farklılıkları Normalleştirilmiş Fark Bitki Örtüsü İndeksi (NDVI) kullanarak incelenmiştir. 2000 ve 2016 yıllarına ait LANDSAT uydu görüntüleri ISODATA yöntemi kullanılarak analiz edilmiş ve CORINE sınıflandırma çerçevesinin üçüncü düzeyine göre 16 arazi kullanımı tespit edilmiştir. Sonuçlar, en büyük değişimin tarım alanlarında meydana geldiğini, sulanmayan ekilebilir arazilerde \%2,57'lik bir azalma, sürekli sulanan arazilerde ise \%7,14'lük bir artış olduğunu göstermişstir. Bölgedeki nüfus azalmasına rağmen kesintisiz kentsel doku $\% 0,07$ oranında artmıştır ve ormanlık alanlarda \%7,62 artış gözlenmiştir. Tespit edilen değişikliklerin, Ekosistem Hizmetleri Ortak Sınıflandırması (CICES) çerçevesine dayalı olarak olumlu veya olumsuz etkileri değerlendirilmiştir. Su kütleleri ve doğal peyzaj alanlarındaki azalmaya rağmen tarım alanlarındaki, ormanlardaki ve yapay yüzeylerdeki artışların ilçedeki ekosistem hizmetleri değerlemesini olumlu etkilediği belirlenmiştir.

To Cite: Tokgöz G., Say N. Quantification of the Impact of Land Use/Land Cover Changes on Ecosystem Services: A Case Study in AdanaKaraisalı. Osmaniye Korkut Ata Üniversitesi Fen Bilimleri Enstitüsü Dergisi 2021; 4(3): 466-482. 


\section{Introduction}

Changes in land cover and land use, which are caused by global environmental changes and human activity, significantly affect the energy balance of the world and biogeochemical cycles. While such changes can result in climate changes, they can also change terrain features and the provision of ecosystem services (Turner et al., 2007; Foley et al., 2005; Soley et al., 2016). Ecosystem Services (ES) have become a focal point of interest for environmental policies and actions in recent years, and started to be included in planning and policy making processes (Costanza et al., 1997). Lam and Conway (2008) conducted a case study in Ontario, Canada in order to describe how ecosystem services were incorporated in land use plans. This study revealed the significance of incorporating a working definition of ecosystem services in policy documents and adopting a broader focus on a greater variety of ecosystem services. He et al. (2018) studied on a guidance for land use decision makers to describe ecological restoration policies and optimize land use planning. Research on ecosystem services has increased since the Millennium Ecosystem Assessment in 2005 and ecosystem services assessment research and policy have grown as fields of study (MEA, 2005). The foundation of the Economics of Ecosystems and Biodiversity (2010) initiative and the Intergovernmental Science-Policy Platform on Biodiversity and Ecosystem Services (IPBES, 2015) are global examples indicating the importance of this topic worldwide. Economic assessment of ecosystem services are becoming regular part of practice in ecological economics in order to develop the foundations of politic and planning decisions and create a deeper knowledgebase with regards to the importance of ES (Costanza, 2006; Costanza et al., 2012; Costanza et al., 2014). ES assessment research is a tool that can contribute to increasing awareness of the importance of ES (Costanza et al., 2014). Ecosystems, which consist of plant, animal, and micro-organism communities and unanimated environments all of which interact with each other as functional units both directly and indirectly, provide a wide array of services to human being including raw materials for food, fibre, and industry as well as water supplies (Costanza, 1997; MEA, 2005; Braat and Groot, 2012; Kındu et al., 2016; Li et al., 2017; Gashaw et al., 2018). According to Millennium Ecosystem Assessment report, 15 out of the 24 ecosystem services assessed were either broken down or disappeared, and that loss posed a direct threat to eco-security on the local and global scale (MEA, 2005). The fact that farming lands constitute $11 \%$ of global land areas and that pasture lands increased from 324 million hectares in year 1700 to 3,429 million hectares in year 2000. Pielke et al. (2011) shows the extent of the effect caused by human beings. Similarly, research underlined that changes in land use have a significant impact on an ecosystem's service providing capacity. Global land use changes between 1997 and 2011 are estimated to have costed 4.3 to 20.2 trillion US Dollars’ worth of ES loss (Costanza et al., 2014). Understanding the link between ES and land use changes have resulted in increased interest among researchers and international groups for studying ecosystem restorations, management, and preservation (Quintas-Soriono et al., 2016). Nevertheless, in spite of the increased interest on studying ES, studies investigating this concept in relation to land use changes are still limited. The present study aimed to investigate the effects of LULC changes in Adana-Karaisalı district of Turkey on ecosystem services.

Main ecosystem services are diverse due to various kinds of land use (MEA, 2005; Baral et al., 2013). For example, while a forest ecosystem provides different services when compared to pasture or aquatic ecosystems, dense forests provide different ecosystem services in comparison to light forests (Anaya- 
Romera et al., 2016; Tolessa et al., 2017). In other words, while timber production, carbon reserve, and water holding capacity is higher in forests when compared to wetlands, pasture and farm lands; provision of water and water regulation services are higher in wetlands in comparison to other kinds of land use. Pasture and farm lands, on the other hand, provide better services for food supply and feed manufacturing than other kinds of land use (Baral et al., 2013). LULC changes affect vegetation, anthropogenic factors, ecosystem type and state, and ecosystem service flow. Similarly, it has been found that changes in land use impact on main ecological processes such as energy exchange, soil erosion, water cycle, and biogeochemical cycles. Tang et al. (2014) examined the temporal variation in ecosystem services in response to land cover changes. This research study provided guidance for regional sustainable development. Srivastava et al. (2013) conducted a research study to determine the water quality status of the area and to describe its relation to seasonal variations in land use/land cover (LULC) changes. It is important to identify changes in LULC to manage ecosystems in an integrated manner in an effort to provide multiple services (Braat and Groot, 2012; Jacobs et al., 2016). Ecosystem services provided by a certain environment can be classified using various frameworks. Popular frameworks include Millennium Ecosystem Assessment, the Economics of Ecosystems and Biodiversity (TEEB, 2010), and the Common International Classification of Ecosystem Services (CICES, 2013).

According to MEA framework of classification, ecosystem services have four main categories (provisioning, regulating, supporting, and cultural services), CICES framework, on the other hand, includes three main classification categories; provisioning, regulating, and cultural services (MEA, 2005; Braat and Groot, 2012; Anaya-Romero et al., 2016; Kındu et al., 2016; Costanza et al., 2017). The present study benefitted from the CICES framework whilst relating ecosystem services to LULC. The development of remote sensing technologies facilitated the process of mapping and categorizing lands that have been changed as a result of human activity or natural causes. Changes in LULC are one of the most visible modifications of the terrestrial ecosystem by human beings. Such changes have significant impact on local, regional, and global environment (CICES, 2013). Studies to identify LULC are being conducted to develop farming economies, analyse changes in forest lands, manage natural resources, and support urban planning and archaeological research. Such studies utilize various methods and strategies to observe changes in LULC over time and one of the most commonly used methods is to compare classification results. This method compares results of satellite image classifications for different time periods and identifies land use changes (Kayman, 2015). Nevertheless, it is possible that the use of only satellite images has the potential to result in errors where surface objects cannot be distinguished from one another, thus, causing erroneous classifications. In addition to satellite images, surface characteristics can be used as auxiliary data in order to increase the distinguishability of the objects in images for a more reliable classification (Edunius et al., 2003; Wright and Gallant, 2007). One such commonly used method is the Normalized Difference Vegetation Index (NDVI) which allows differentiating vegetation on satellite images from other types of land cover. NDVI is defined as the division of the difference between near infrared (NIR) and visible red (RED) band on the electromagnetic spectrum (Gandhi, 2015).

NDVI data has been successfully used in various parts of the world by researchers especially for investigating and identifying vegetation changes in large areas of land. NDVI is more advantageous compared to traditional 
methods due to lower costs and expeditious processing of data regarding vegetation change. More specifically, vegetation index values obtained from daily satellite data provides substantial advantages (Yang et al., 1997). In relation to this, Karabulut (2006) has investigated main vegetation changes in Turkey using NDVI. Similarly, Mermer et al. (2011) have analysed seasonal changes of pasture lands using NDVI. Such data can be used to calculate seasonal Leaf Area Index (LAI) and biomass which extent to covers land (Tucker et al., 1980). These parameters have been found to be associated with soil fertility, soil moisture, seed-time, and plant density (Teng, 1990). The present study has analysed multi-temporal NDVI data using VAST software and aimed to map temporal and spatial changes in Karaisalı's vegetation using VAST output (Y1ld1z et al., 2010). Likewise, Na et al. (2010) have classified Landsat TM images and integrated the main components of the NDVI output produced from those images into their study. They have concluded that the accuracy rate of their classification significantly increased as a result of using NDVI output. In addition, Xiaodong et al. (2009) have integrated auxiliary data such as elevation and soil type. Kumar et al. (2011) have taken many auxiliary data such as digital elevation model, elevation, aspect, NDVI, configuration, and contrast into consideration and noted that such auxiliary data positively affects the accuracy of classifications. Chen et al. (2005) have underlined the importance of satellite images for observing land cover change over time in large scale areas. They have developed a new method used images that date back to different times to accurately identify land cover change. This new method is simple, effective, and repeatable in producing data sets which could be compared radio metrically. When compared to other radiometric normalization methods, Chen et al. (2005)'s method is found to not require advanced programming or statistics knowledge; nevertheless, the method is able to produce detailed data that can be used to identify changes in land. Zhang and Li (2020) have researched the landscape, plant distribution and animal distribution in a constructed wetland of the Yellow River Basin. The study has revealed that the water body has the significant impact on landscape integrity.

Understanding the link between ES and land use changes has resulted in increased interest among researchers and international groups for studying ecosystem restorations, management, and preservation (Quintas-Soriono et al., 2016). Nevertheless, in spite of the increased interest on studying ES, the studies investigating this concept in relation to land use changes are still limited. Main ecosystem services are diverse due to various kinds of land use (MEA, 2005; Baral et al., 2013). For example, while a forest ecosystem provides different services when compared to pasture or aquatic ecosystems, dense forests provide different ecosystem services in comparison to light forests (Anaya-Romera et al., 2016; Tolessa et al., 2017). In other words, while timber production, carbon reserve, and water holding capacity is higher in forests when compared to wetlands, pasture and farm lands; provision of water and water regulation services are higher in wetlands in comparison to other kinds of land use. Pasture and farm lands, on the other hand, provide better services for food supply and feed manufacturing than other kinds of land use (Baral et al., 2013). The present study has aimed to investigate the effects of LULC changes in Adana-Karaisalı district of Turkey on ecosystem services. 


\section{Materials and Methods}

\section{Study Area}

Karaisalı district, the study area in this research, is located at $37^{\circ} 8^{\prime} 00^{\prime \prime} \mathrm{N}-37^{\circ} 28^{\prime} 00^{\prime \prime} \mathrm{N}$ latitude and $34^{\circ} 55^{\prime}$ $00^{\prime \prime} \mathrm{E}-35^{\circ} 25^{\prime} 00^{\prime \prime} \mathrm{E}$ longitude (Fig. 1). The district is placed on the north of Adana Province of Turkey and south edges of Toros Mountains. The land consists of mountainous, rugged, and flat areas. Çatalan and Nergizlik dams located in the area are sources of drinking water for the district (Anonymous, 2016a). Located in the Mediterranean Region, summers are hot and dry and winters are mild and rainy in the district. Rainfall generally occurs in the form of orographic rain or when two air masses meet. Average annual rainfall is 917 $\mathrm{mm}$. The air is hot and humid especially during summer. 38-year average annual heat of the district is $18.3^{\circ} \mathrm{C}$ (Anonymous, 2016b). Located in the flora zone of Eastern Mediterranean, the vegetation of the district includes xerophilous trees and bushes which have hard green leaves year around (Y1lmaz, 1996). Pinus brutia also known as Turkish pine is the signature plant of the region. Pinus brutia forests, maquis, and herbaceous plants constitute the vegetation of the district. The district which consists of a total of 62 neighbourhoods had a population of 60.601 in 1985; however, the population of the district decreased over time and the census data for 2016 indicated that there were 21.250 people residing in Karaisalı (TUIK, 2016). Most of the residents makes their living from farming and animal rearing activities.

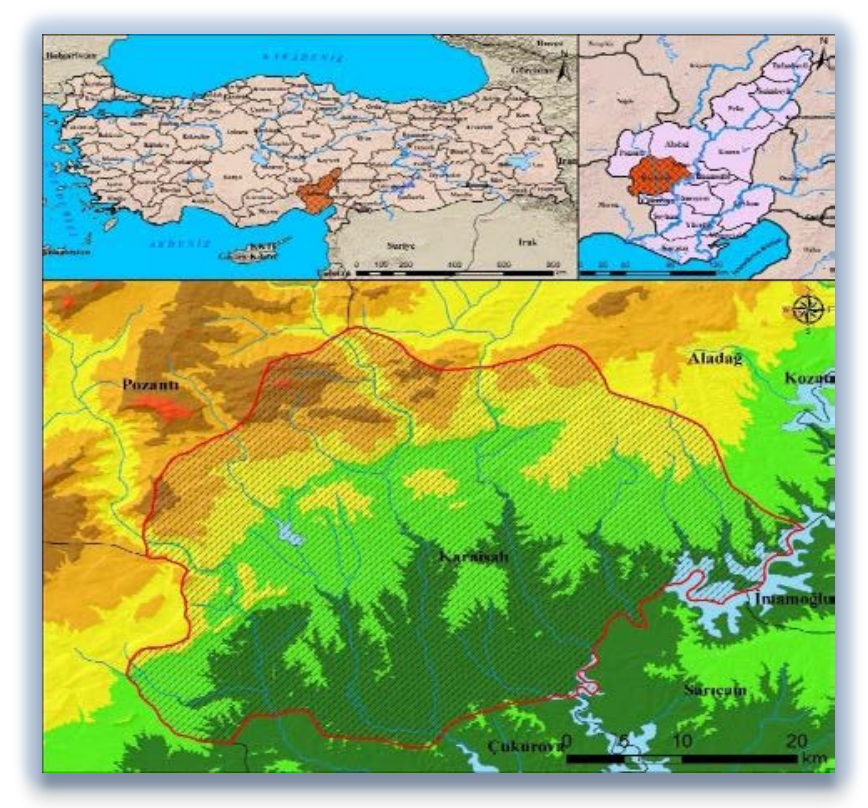

Figure 1. Study area location map

\section{Methods}

The proper land use requires taking into consideration of various characteristics, such as topography (i.e. elevation, aspect, and land forms), main materials and soil. The suitability of a piece of land to be used as farming land or forest depends on which activity (i.e. farming) would generate the maximum efficiency on that particular land. Answering questions such as which areas can be used as farms, pastures, forests, settlements, or industrial areas is possible by accurate classification and use of lands. Appropriate use of land 
requires revealing the natural potential of the land and administering feasibility analyses which can be realized through quantitative analysis of components in the environment. Software which has been developed using computer and satellite technologies (specifically Geographic Information Systems), based on quantitative data, facilitates the process of revealing land potential, administering feasibility analysis for land use, and observing changes in a specific area (Pektezel and Ateş, 2016).

Because of being close to Adana city centre and having high natural potential, Karaisalı district has been one of the districts which are prioritized for development. In line with this, Landsat 7 ETM images of Karaisal1 from 2000 and Landsat 8 OLI images from 2016, which were provided by United States Geological Survey were used in order to create a classification map of Karaisalı, identify the changes that took place over time, and determine areas important for ecosystem services. For the consistency of the classification, attention was paid to ensure that reflection values and dates on which pictures were taken were close to each other. Images in the study were atmospherically corrected and ISODATA method was utilized to perform unsupervised classification. ISODATA is Iterative Self-organizing Data Analysis Technique, which is an iterative selforganizing data analysis technology (Zhao and Zhou, 2016). The ISODATA method is based on the minimum distance center method object meta-clustering. Method can select the initial class clustering center according to certain principles, and then calculate the standard deviation of each cluster and the distance between each class center. The smaller the distance, the larger the similarity, the easier it is to belong to the same class. If the cluster standard deviation deviation is greater than the defined threshold, the split is selected. If the class spacing is less than the defined threshold, then merge. The cluster center is continuously calculated and iterated until the average class spacing is less than the defined threshold or the average of the two iterative process class spacings is less than the threshold ( $\mathrm{Li}$ et al., 2020). Unsupervised classification which works on the principle of minimum distance is an automatic classification method and is carried out based on the statistical groups of the models that are created by reflected values. In this study land cover classification was completed using ERDAS 9.1 and ArcGIS 10.4.1 software and land cover changes were identified. Following classification, change analyses were carried out and changes between land categories were determined and interpreted. NDVI values and land use maps that were generated were utilized as auxiliary data in order to identify changes in the area.

Normalized Difference Vegetation Index (NDVI) is a method that is used to determine whether a given area has vitality or not by using near infrared (NIR) and visible red (RED) bands of the electromagnetic spectrum. NDVI is generally directly proportional to surface cover, plant photosynthesis activity, surface water, biomass, and leaf area index (LAI) percentages (Rouse et al., 1973). Healthy vegetation reflects most of the near infrared light that falls onto it and absorbs visible light. Sparse vegetation, on the other hand, reflects more RED and less NIR, and bare soil moderately reflects both NIR and RED parts of the electromagnetic spectrum. Plants' behaviour in the electromagnetic spectrum can be obtained using Landsat bands and this way NDVI values can be calculated. The higher the reflection differences between NIR and RED, the greater the amount of green vegetation in the observed area. NDVI value is calculated by dividing the difference between NIR and RED values to the addition of NIR and RED (Osunmedewa et al., 1973). Theoretically, NDVI is a value between 1 and +1 . 


\section{Results}

\section{Land use/land cover classification}

The "Coordination of information on the environment" (CORINE) is an inventory of European land cover split into 44 different land cover classes (Url 1). The CORINE Land Cover (CLC) inventory was initiated in 1985 to standardize data collection on land in Europe to support environmental policy development. The project is coordinated by the European Environment Agency (EEA) in the frame of the EU Copernicus programme and implemented by national teams. The number of participating countries has increased over time currently including 33 (EEA) member countries and six cooperating countries (EEA39) with a total area of over 5.8 Mkm2 (Url 2).

The land use/land cover (LULC) maps of Karaisalı created in line with the CORINE classification system and belonging to 2000 and 2016 are presented in Figure 2 and Figure 3. Changes detected based on these maps are summarized in Table 1. The accuracy rate of the satellite map classification produced in the present study was calculated as $81.20 \%$ and accuracy rate calculations are detailed in Table 2 . The results suggested that the most significant changes took place in agricultural areas. While non-irrigated arable land areas decreased $2.57 \%$ over the course of 16 years, the area of permanently irrigated farming increased $7.14 \%$. In spite of the decline of population in the district, continuous urban fabric increased $0.07 \%$. The decline in pasture land area in this district where animal rearing is important- is notable. Nevertheless, forestation activities in the district resulted in significant increases in forest lands. The results generated based on the classification of satellite images from 2016 indicated that agricultural areas (both non irrigated arable land and permanently irrigated land) covered an area of 1.941.92 hectares, and natural lands and forests covered an area of 80.803.29 hectares (Tokgöz, 2018).

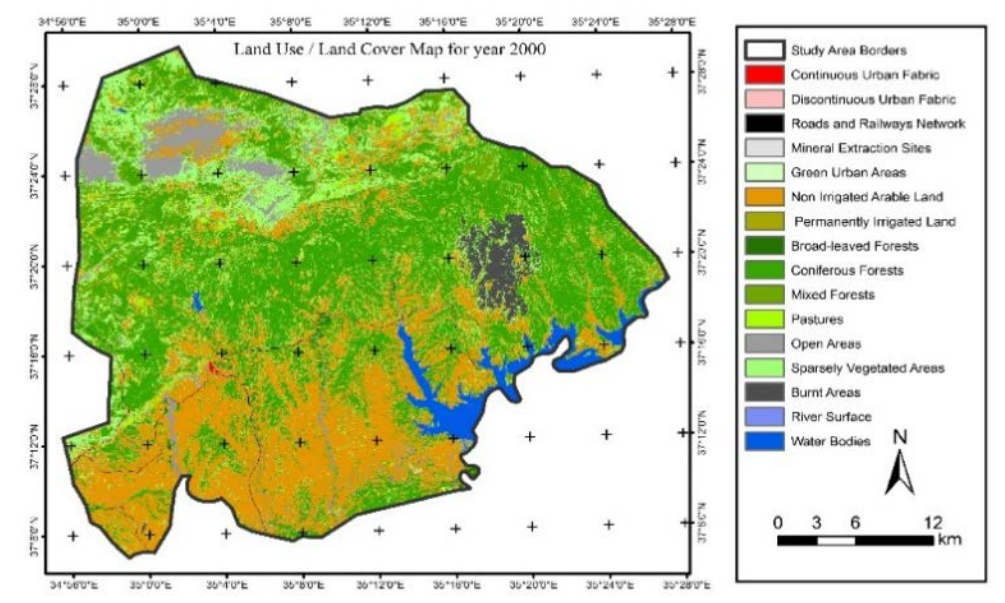

Figure 2. Land Use/Land Cover for 2000 (Tokgöz, 2018) 

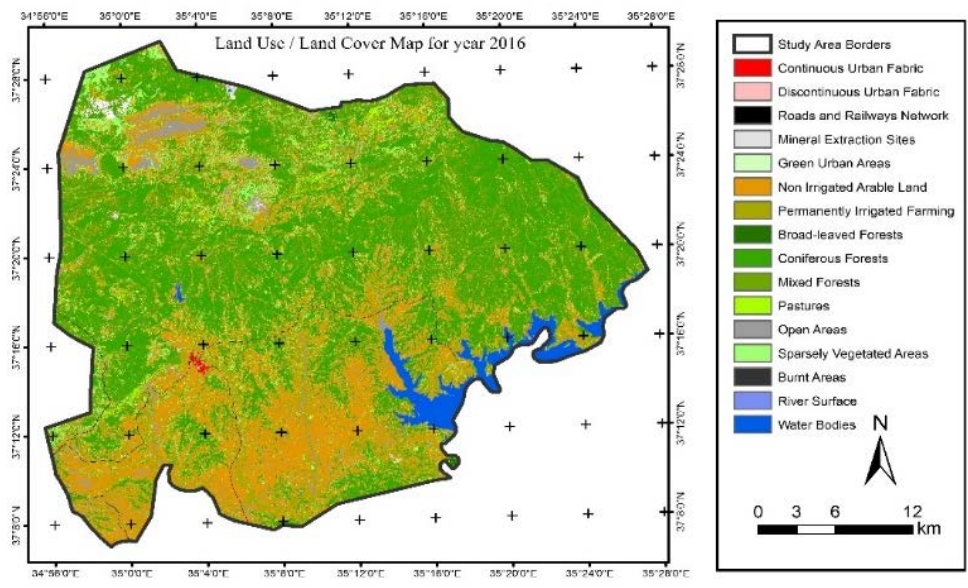

Figure 3. Land Use / Land Cover for 2016 (Tokgöz, 2018)

Table.1. Land use/land cover changes between 2000 and 2016 (Tokgöz, 2018)

\begin{tabular}{|c|c|c|c|c|c|c|c|}
\hline $1^{\text {st }}$ Level & $\begin{array}{c}\text { CORINE } \\
\text { Land Cover } \\
\text { Code }\end{array}$ & $3^{\text {rd }}$ Level & $\begin{array}{c}\text { Year } 2000 \\
\text { Size (ha) }\end{array}$ & $\begin{array}{l}\text { Size } \\
(\%)\end{array}$ & $\begin{array}{l}\text { Year } 2016 \\
\text { Size (ha) }\end{array}$ & $\begin{array}{l}\text { Size } \\
(\%)\end{array}$ & $\begin{array}{c}\text { Amount } \\
\text { of } \\
\text { changed } \\
\text { land (\%) }\end{array}$ \\
\hline \multirow[t]{5}{*}{$\begin{array}{l}\text { 1.Artificial } \\
\text { Surfaces }\end{array}$} & 1.1 .1 & $\begin{array}{l}\text { Continuous Urban } \\
\text { Fabric }\end{array}$ & 30.85 & 0.02 & 103.81 & 0.08 & 0.06 \\
\hline & 1.1.2 & $\begin{array}{l}\text { Discontinuous Urban } \\
\text { Fabric }\end{array}$ & 18.95 & 0.01 & 19.41 & 0.02 & 0.01 \\
\hline & 1.2 .2 & $\begin{array}{l}\text { Roads and Railways } \\
\text { Networks }\end{array}$ & 280.02 & 0.22 & 263.83 & 0.21 & -0.01 \\
\hline & 1.3 .1 & $\begin{array}{l}\text { Mineral Extraction } \\
\text { Sites }\end{array}$ & 13.83 & 0.01 & 140.92 & 0.11 & 0.10 \\
\hline & 1.4.1 & Green Urban Areas & 11.35 & 0.01 & 31.06 & 0.02 & 0.01 \\
\hline \multirow[t]{2}{*}{$\begin{array}{l}\text { 2.Agricultural } \\
\text { Areas }\end{array}$} & 2.1.1 & $\begin{array}{l}\text { Non - irrigated Arable } \\
\text { Land }\end{array}$ & 34.870 .37 & 27.41 & 31.591 .65 & 24.84 & -2.57 \\
\hline & 2.1.2 & $\begin{array}{l}\text { Permanently - irrigated } \\
\text { Land }\end{array}$ & 1.269 .45 & 1.00 & 10.350 .27 & 8.14 & 7.14 \\
\hline \multirow{5}{*}{$\begin{array}{l}\text { 3.Forest } \\
\text { /Seminatural } \\
\text { Areas }\end{array}$} & 3.1.1 & Broad-leaved Forests & 423.68 & 0.33 & 108.96 & 0.09 & -0.24 \\
\hline & 3.1.2 & Coniferous Forests & 37.052 .99 & 29.13 & 43.690 .44 & 34.35 & 5.22 \\
\hline & 3.1 .3 & Mixed Forests & 17.486 .73 & 13.75 & 20.843 .80 & 16.39 & 2.64 \\
\hline & 3.3.3 & $\begin{array}{l}\text { Sparsely Vegetated } \\
\text { Areas }\end{array}$ & 21.730 .29 & 17.08 & 11.738 .02 & 9.23 & -7.85 \\
\hline & 3.3 .4 & Burnt Areas & 2.658 .91 & 2.09 & 219.25 & 0.17 & -1.92 \\
\hline \multirow{4}{*}{$\begin{array}{l}\text { 4.Natural } \\
\text { Areas/Wetlands } \\
\text { 5. Water Bodies }\end{array}$} & 4.1.1 & Pastures & 1.012 .90 & 0.80 & 768.48 & 0.60 & -0.20 \\
\hline & 4.1.2 & Open Areas & 6.156.77 & 4.84 & 3.434.34 & 2.70 & -2.14 \\
\hline & 5.1 .1 & River Surface & 146.52 & 0.12 & 3.633 .95 & 2.86 & 2.74 \\
\hline & 5.1 .2 & Water Bodies & 4.033 .65 & 3.17 & 259.07 & 0.20 & -2.97 \\
\hline
\end{tabular}


Table 2. Accuracy Rate of the 2016 Satellite Image Classification (Tokgöz, 2018)

\begin{tabular}{|c|c|c|c|c|c|}
\hline Classification Type & $\begin{array}{l}\text { Total Number } \\
\text { of References }\end{array}$ & $\begin{array}{c}\text { Total } \\
\text { Number of } \\
\text { Classified } \\
\text { Data } \\
\end{array}$ & $\begin{array}{c}\text { Number } \\
\text { of } \\
\text { “Correct” } \\
\text { Matches } \\
\end{array}$ & $\begin{array}{c}\text { Producer } \\
\text { Accuracy } \\
(\%) \\
\end{array}$ & $\begin{array}{c}\text { User } \\
\text { Accuracy (\%) } \\
\end{array}$ \\
\hline Continuous Urban Fabric & 4 & 10 & 8 & 100.00 & 80.00 \\
\hline Discontinuous Urban Fabric & 8 & 10 & 8 & 100.00 & 80.00 \\
\hline Roads and Railways Network & 8 & 10 & 7 & 75.00 & 60.00 \\
\hline Mineral Extraction Sites & 15 & 15 & 15 & 100.00 & 100.00 \\
\hline Green Urban Areas & 15 & 12 & 9 & 60.00 & 75.00 \\
\hline Non -irrigated Arable Land & 26 & 22 & 16 & 61.54 & 72.73 \\
\hline Permanently -irrigated Land & 15 & 21 & 15 & 100.00 & 80.00 \\
\hline Broad-leaved Forests & 8 & 10 & 8 & 100.00 & 80.00 \\
\hline Coniferous Forests & 61 & 42 & 39 & 76.47 & 92.86 \\
\hline Mixed Forests & 22 & 18 & 16 & 72.73 & 88.89 \\
\hline Pastures & 10 & 10 & 10 & 100.00 & 100.00 \\
\hline Open Areas & 5 & 6 & 5 & 100.00 & 83.33 \\
\hline Sparsely Vegetated Areas & 14 & 14 & 12 & 85.71 & 85.71 \\
\hline River Surface & 12 & 15 & 12 & 100.00 & 80.00 \\
\hline Water Bodies & 18 & 18 & 18 & 100.00 & 100.00 \\
\hline Total & 250 & 239 & 203 & & \\
\hline
\end{tabular}

As can be seen in Figure 4, NDVI values are closer to +1 in areas where there is a healthy vegetation, and they drop and get closer to -1 in areas such as water surfaces, bare soil, and settlements. The comparison of NDVI values for 2000 and 2016 suggests that vegetation in the area has increased over the course of 16 years. While NDVI can be used as an indicator of relativistic biomass, leaf area index (LAI), and vegetation (Zhang et al., 2007). It has also been associated with functional characteristics such as primary production and carbon offset in a number of studies (Hueta et al., 2002) and has been considered as an important characteristic of ecosystem service analysis (Rocez-Diaz et al., 2014). Therefore, it is assumed that there is a linear relationship between ecosystem service value and NDVI (Wang et al., 2015). In line with CICES classification, ecosystem services identified in this study have been classified under three main headings and a total of 31 sub-categories, and these categories have been associated with LULC categories (Table 3).

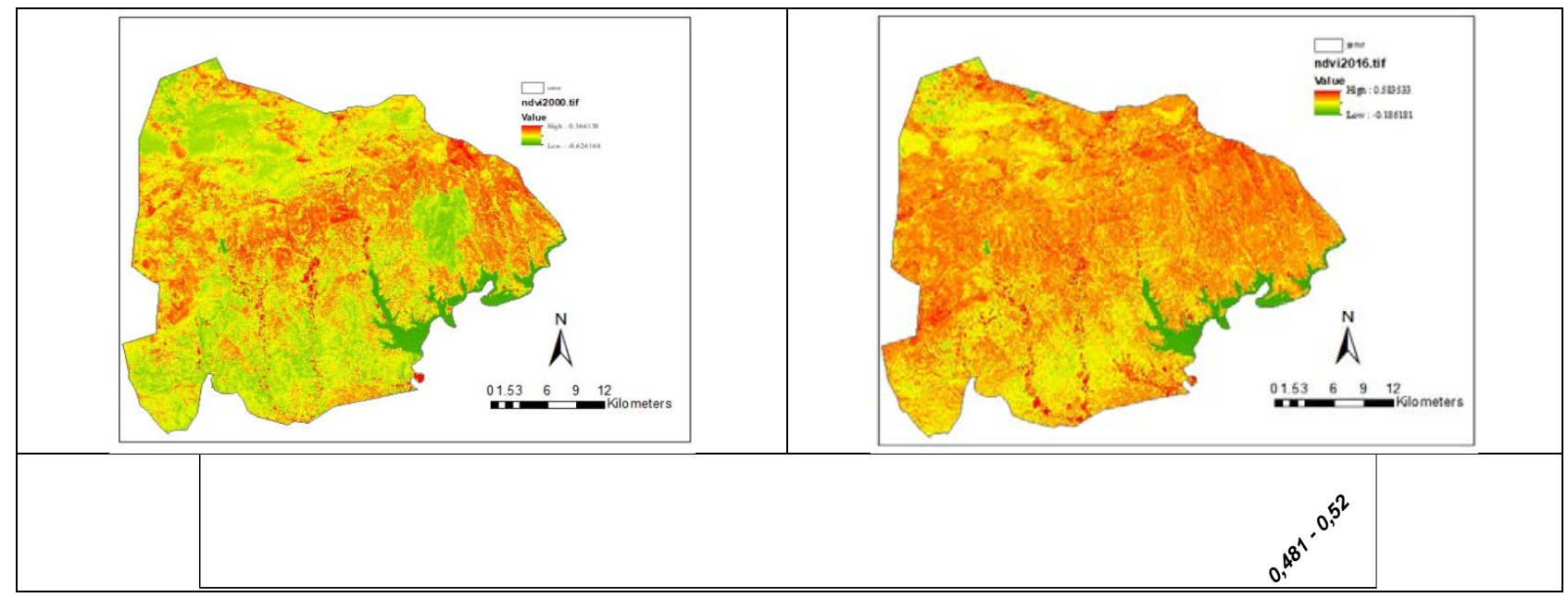

Figure 4. NDVI values for 2000 and 2016 (Tokgöz, 2018) 
There are various direct and indirect methods to value ecosystem services which have their own strengths and weaknesses and require time and resources (De Groot et al., 2002; Farber ae al., 2006; Msofe et al., 2020). The present study utilized the benefit transfer method in order to transfer the worth of ecosystem services to LULC. Benefit transfer method is a method used to estimate ecosystem services values when an original valuation study is not available for a specific location or context (Coztanza, 1997; Kubiszewski et al., 2013). Two kinds of ecosystem services valuation (ESV) coefficients have been used for LULC categories. The first kind of coefficients is the one that has been used as a reference point in many studies and treated as global ecosystem coefficients by Costanza et al. (1997). And the second kind of coefficients includes the values that have been obtained from the Economics of Ecosystems Biodiversity (TEEB) valuation data base and the study reported by Sharma et al. (2019). LULC data were evaluated in a geographic information systems (GIS) environment and land use for biome types in 2000 and 2016 was calculated in hectares (ha). Value coefficients were calculated for each LULC category based on global coefficients used by Costanza et al. (1997) and coefficients modified by Sharma et al. (2019) and TEEB (2010), (Table 3 and Table 4). Afterwards, each land cover's use category (in hectares) was multiplied with related coefficient values in order to identify total ESV (Sharma et al., 2019). Lastly, changes in ecosystem services values were calculated by subtracting ESV values for 2016 from ESV values for 2000 in each use category. While positive figures indicate an increase in total value, negative figures indicate a decrease.

Table. 3 Estimated Ecosystem Service Valuations Based on Land Use/ Land Cover and Ecosystem Service

\begin{tabular}{|c|c|c|c|c|c|c|}
\hline & Ecosystem Service Type & $\begin{array}{l}\text { Artificial } \\
\text { Surfaces }\end{array}$ & $\begin{array}{l}\text { Agricultural } \\
\text { Areas }\end{array}$ & Forests & $\begin{array}{l}\text { Natural } \\
\text { Areas }\end{array}$ & $\begin{array}{l}\text { Water } \\
\text { Bodies }\end{array}$ \\
\hline & $\begin{array}{l}\text { Regulation and } \\
\text { Maintenance Services }\end{array}$ & & & & & \\
\hline 1. & Global Climate Regulation & 1 & 4 & 91 & 0 & 0 \\
\hline 2. & Local Climate Regulation & 1 & 4 & 104 & 0 & 0 \\
\hline 3. & Air Quality Regulation & 1 & 4 & 54 & 7 & 0 \\
\hline 4. & Water Flow Regulation & 1 & 3 & 34 & 2 & 0 \\
\hline 5 & Water Purification & 0 & 1 & 14 & 2 & 378 \\
\hline 6. & Food Regulation & 0 & 6 & 2 & 0 & 0 \\
\hline 7. & Erosion Control & 0 & 2 & 36 & 22 & 0 \\
\hline 8 & Natural Risk Reduction & 0 & 0 & 12 & 0 & 0 \\
\hline 9. & Pollination & 1 & 8 & 33 & 24 & 0 \\
\hline 1. & Pest and Disease Control & 1 & 2 & 0 & 23 & 0 \\
\hline \multirow[t]{2}{*}{11.} & Mediation of Wastes & 0 & 1 & 65 & 87 & 81 \\
\hline & Provisioning Services & & & & & 0 \\
\hline 12. & Crops & 1 & 15 & 7 & 5 & 50 \\
\hline 13. & Energy and biomass & 1 & 4 & 24 & 12 & 0 \\
\hline 14. & Feed & 0 & 8 & 2 & 25 & 0 \\
\hline 15. & Husbandry & 0 & & 0 & 29 & 0 \\
\hline 16. & Fibre & 0 & 2 & 16 & 0 & 0 \\
\hline 17. & Timber & 0 & 0 & 174 & 0 & 0 \\
\hline 18. & Wood & 0 & 0 & 141 & & 0 \\
\hline 19. & Fish, seafood, algae & 0 & 0 & 0 & 0 & 0 \\
\hline 20. & Aquaculture & 0 & 0 & 0 & 0 & 0 \\
\hline 21. & Wild Food Sources & 0 & 6 & 15 & 0 & 0 \\
\hline 22. & Biochemicals and Medicine & 0 & 2 & 6 & 0 & 0 \\
\hline 23. & Fresh Water & 0 & 1 & 8 & 0 & 1872 \\
\hline 24. & Mineral Resources & 2 & 1 & 0 & 1 & 0 \\
\hline 25. & $\begin{array}{l}\text { Abiotic Energy Resources } \\
\text { Cultural Services }\end{array}$ & 1 & 1 & 0 & 3 & 0 \\
\hline 26. & $\begin{array}{l}\text { Recreation and sense of } \\
\text { space }\end{array}$ & 2 & 1 & 9 & 2 & 318 \\
\hline 27. & $\begin{array}{l}\text { Landscape Aesthetics and } \\
\text { Inspiration }\end{array}$ & 2 & 2 & 4 & 0 & 0 \\
\hline
\end{tabular}




\begin{tabular}{llllllll}
\hline $\mathbf{2 8}$ & $\begin{array}{l}\text { Information Systems } \\
\mathbf{2 9}\end{array}$ & $\begin{array}{l}\text { Spiritual and Ethical Values } \\
\mathbf{3 0}\end{array}$ & 2 & 1 & 5 & 0 & 0 \\
& $\begin{array}{l}\text { Natural Heritage } \\
\mathbf{3 1}\end{array}$ & 2 & 4 & 5 & 0 & 0 & 0 \\
$\begin{array}{l}\text { Species Diversity } \\
\text { Cultural Heritage } \\
\text { Cultural Diversity }\end{array}$ & and & 2 & 2 & 2 & 0 & 0 \\
\hline & Total ESV Dispersion: & $: 22$ & 92 & 1871 & 244 & 2699 \\
\hline
\end{tabular}

Table 4. LULC Categories and Their ESV Which Correspond to Values in Study (Foley et al., 2005)

\begin{tabular}{|c|c|c|c|c|}
\hline \multirow{2}{*}{$\begin{array}{l}\text { Corine Land } \\
\text { Cover } 1^{\text {st }} \\
\text { Level }\end{array}$} & \multirow[t]{2}{*}{$\begin{array}{l}\text { Land Cover } \\
\text { Category }\end{array}$} & \multirow[t]{2}{*}{ Equivalent Biome Type } & \multicolumn{2}{|c|}{$\begin{array}{l}\text { Total Ecosystem Service Value (in US } \\
\text { Dollars/ ha/ year) }\end{array}$} \\
\hline & & & $\begin{array}{l}\text { Costanza et al. } \\
\text { (1997) }\end{array}$ & $\begin{array}{l}\text { Adapted TEEB } \\
\text { (2010); Sharma et } \\
\text { al. (2019) }\end{array}$ \\
\hline 1. & Artificial Surfaces & $\begin{array}{l}\text { Urban areas, Mine Mineral } \\
\text { Extraction Sites, Roads } \\
\text { and Railways }\end{array}$ & 22 & 22 \\
\hline 2. & Agricultural Areas & $\begin{array}{l}\text { Non-irrigated and } \\
\text { Permanently-irrigated } \\
\text { Lands }\end{array}$ & 92 & 92 \\
\hline 3. & $\begin{array}{l}\text { Forests and } \\
\text { Seminatural Areas }\end{array}$ & $\begin{array}{l}\text { Broad-leaved, Coniferous } \\
\text { Forest, and Mixed Forests }\end{array}$ & 2007 & 1871 \\
\hline 4. & Natural Areas & $\begin{array}{l}\text { Pastures and Sparsely } \\
\text { Vegetated Areas }\end{array}$ & 232 & 244 \\
\hline 5. & Water Bodies & $\begin{array}{l}\text { River Surfaces and Water } \\
\text { Bodies }\end{array}$ & 8498 & 2699 \\
\hline
\end{tabular}

Estimation of Ecosystem Services Values and Changes

The total ESV was calculated using the following formula:

$\mathbf{E S V}=\sum\left(\mathbf{A}_{\mathbf{k}} \times \mathbf{V}_{\mathbf{k}}\right)$

ESV is the total ecosystem service value; $\mathbf{A}_{\mathbf{k}}$ is the area in ha, and $\mathbf{V}_{\mathbf{k}}$ is the value coefficient (US\$ ha $\mathrm{yr}^{-1}$ ) for land-use category k (Kindu et al., 2016; Gashaw et al., 2018)

Table 5. ESV values for 2000-2016 in each use category

\begin{tabular}{clcccc}
$\begin{array}{l}\text { Corine Land } \\
\text { Cover } \mathbf{1}^{\text {st }} \text { Level }\end{array}$ & $\begin{array}{l}\text { Land Cover } \\
\text { Category }\end{array}$ & ESV(Annual in Million US Dollars) & $\begin{array}{l}\text { ESV } \\
\text { (Annual } \\
\text { Dollars) }\end{array}$ & $\begin{array}{l}\text { Change } \\
\text { in }\end{array}$ \\
\hline & & 2000 (approximately) & $\begin{array}{c}\mathbf{2 0 1 6} \\
\text { US }\end{array}$ \\
\hline (approximately) & \\
\hline 1. & Artificial Surfaces & 7810 & 12298 & 4488 \\
3. & Agricultural Areas & 3325 & 3859 & 534 \\
& Forests and Semi- & 47873 & 56304 & 8431 \\
4. & natural Areas & 7700 & 3943 & -3757 \\
5. & Natural Areas & 11282 & 10507 & -775 \\
\hline
\end{tabular}




\section{Conclusions}

Detecting environmental changes using two or more satellite images of a specific geographical location or area taken at different points in time is one of the methods currently available to determine changes in land use and land cover (LULC). Such data are successfully used in various practices such as monitoring urban areas, agricultural development, and forest management. The present study investigated LULC changes between 2000 and 2016 in the Karaisalı district of Adana Province in Turkey using remote sensing and geographic information systems (GIS) technologies. Landsat images were used to conduct analyses. The analyses were conducted using Normalized Difference Vegetation Index (NDVI) which is one of the seven spectral indices that are commonly used to monitor and detect LULC changes. NDVI data and land changes were used together in order to understand ecological processes and activities in the study area over the course of 16 years (20002016). A total of 16 categories related to LULC was identified using the third level of the CORINE framework. ISODATA method was utilized in the present study and the Kappa statistic of the method indicated an 81.20\% accuracy rate. The results suggested that sparsely vegetated areas, open areas, and burned areas decreased over the course of 16 years and farming areas and forests increased. NDVI maps for 2000 and 2016, generated in the light of the data, indicated that plant activity increased positively during the 16-year period. Forestation and irrigated farming activities contributed to this increase. The analyses also suggested that Karaisal1, a district prioritized for rural development, has natural potential for many activities such as farming, animal rearing, water sports, and eco tourism. In line with population growth, man-made changes constitute a considerable amount of LULC changes in regional environment and ecosystem services. However, awareness of ecosystem services at local and regional levels can be used as a supporting tool for stakeholders to manage sustainable land use (Anna et al., 2011). Estimated ecosystem services value (ESV) based on the analysis of the data generated taking LULC changes into account indicate that total ESV value for 2016 is higher than 2000. This is also an indicator of how temporal and spatial scale changes impact upon ecosystem services. In spite of the decrease in water mass and natural areas in 2016, it has been observed that increases in farming areas, forests, and artificial surfaces when compared to 2000 have resulted in 8,921 million US Dollars' worth of total ESV increase. Forests and water mass per hectare create a high ESV. Thus, changing LULC of a particular area whilst preserving its forests and water sources is critical to prevent ESV losses. In addition, loss of farming lands is considered as an emerging threat to food security especially in areas that are being rapidly settled. Therefore, ensuring that lands are used in line with their characteristics becomes critical to provide optimal ecosystem services in a given area. Estimated total ESV found in the present study can be used to communicate the benefits of Karaisalı ecosystems to national and international stakeholders as well as provide an opportunity for further analysis. There are various direct and indirect methods in order to increase the accuracy of ESV estimations. However, those require time and resources. Since the present study is based on a basic benefit transfer method and the values found are estimate values, a planning and management of ecosystem services would require a further and more detailed analysis of Karaisalı district. Sustainability of farming lands, forests, and water sources require innovative policy solutions. The present study can serve as an important source of information for future research and policy making and also provide an opportunity to compare values generated 
in different ecosystems. Moreover, it is important that local authorities include the concept of ecosystem services concept in their plans and policies as a strategy to protect ecosystems and improve sources of income.

\section{Statement of Conflict of Interest}

The authors of the article declare that there is no conflict of interest.

\section{Author's Contributions}

The authors declare that they have contributed equally to the article.

\section{References}

Anaya-Romero M., Muñoz-Rojas M., Ibáñez B., Marañón T. Evaluation of forest ecosystem services in Mediterranean areas. A regional case study in South Spain. Ecosystem Services 2016; 20: 82-90.

Anna H., Sabine S., Thomas W. The concept of ecosystem services regarding landscape research, Living Rev Landscape Res. 2011; 5: 1.

Anonymous. Republic of Turkey Ministry of Forest and Water Affairs, 2016a.

Anonymous. Karaisal1 Mayorship, 2016b.

Baral H., Keenan RJ., Fox JC., Stork NE., Kasel S. Spatial assessment of ecosystem goods and services in complex production landscapes: A case study from south-eastern Australia. Ecol Complex 2013; 13: 3545.

Braat L., de Groot R. The ecosystem services agenda: bridging the worlds of natural science and economics, conservation and development, and public and private policy. Ecosystem Services 2012; 1: 4-15.

Chen X., Vierling L., Deering DA. simple and effective radiometric correction method to improve landscape change detection across sensors and across time. Remote Sensing of Environment 2005; 98: 63-79.

CICES. (Common International Classification of Ecosystem Services) Towards a common international classification of ecosystem services 2013.

Costanza R., de Groot R., Farber S., Grasso M., Hannon B., Limburg K., Naeem S., O’Neill RV., Paruele J., Raskin RG., Sutton P., Van den Belt M. The value of the world's ecosystem services and natural capital. Nature 1997; 387: 253-260.

Costanza R., de Groot R., Braat L., Kubiszewski I., Fioramonti L., Sutton P., Farber S., Grasso M. Twenty years of ecosystem services: How far have we come and how far do we still need to go? Ecosystem Services 2017; 28: 1-16.

Costanza R., de Groot R., Sutton P., Van der Ploeg S., Anderson S., Kubiszewski I., Farber S., Turner R. Changes in the global value of ecosystem services. Glob. Environ. Chang. 2014; 26: 152-158.

Costanza R., Quatrini S., Øystese S. The valuation of nature and ecosystem services is not privatization. Climate Home News 2012.

Costanza R. Nature: Ecosystems without commodifying them. Nature 2006; $443: 749$.

De Groot, RS., Wilson MA., Boumans RMJ. A typology for the classification, description and valuation of ecosystem function, goods and services. Ecological Economics, 2002; 41: 393-408. 
Edenius L., Vencatasawmy CP., Sandstrom P., Dahlberg U., Combining satellite imagery and ancillary data to map snowbed vegetation important to reindeer Rangifer tarandus. Arctic Antarctic and Alpine Research, 2003; 35(2): 150-157.

Farber S., Costanza R., Childers DL., Erickson J., Gross K., Grove M., Hopkinson CS., Kahn J., Pincetl S., Troy A. Linking ecology and economics for ecosystem management. AIBS Bull. 2006; 56: 121-133.

Foley JA. et al. Global consequences of land use. Science 2005; 309: 570-574.

Gandhi GM., Parthiban S., Thummalu N., Christy A. Vegetation change detection using remote sensing and gis -A case Study of Vellore District. Procedia. Computer Science 2015; 57: 119-121.

Gashaw T., Tulu T., Argav T., Worqlul WA., Tolessa T., Kindu M. Estimating the impacts of land use/land cover changes on Ecosystem Service Values: The case of the Andassa watershed in the Upper Blue Nile basin of Ethiopia. Ecosystem Services 2018; 31: 219-228.

He J., Shi X., Fu Y., Yuan Y. Evaluation and simulation of the impact of land use change on ecosystem services trade-offs in ecological restoration areas, China, Land Use Policy 2020; 99: 105020

Huete A., Didan K., Miura T., Rodriguez EP., Gao X., Ferreira LG. Overview of the radiometric and biophysical performance of the MODIS vegetation indices. Remote Sens. Environ.2002; 83: 195-213.

IPBES. Intergovernmental Platform on Biodiversity and Ecosystem Services (IPBES) (http://www.ipbes.net) accessed 12 December 2015.

Jacobs S., Dendoncker N., Martín-lópez B., Nicholas D., Gomez-baggethun E., Boeraeve F., McGrath FL.,Vierikko K., Geneletti D., Sevecke KJ., Pipart N., Primmar E., Mederly P., Schmidth S., Aragao A., Baral H., Bark RH., Briceno T., Brogna D., Cabral P., Vreese RD., Liquete C., Muller H., Peh KSH., Phelan A., Rincon AR., Rogers SH., Turkelboom F., Reeth WV., Zanten BT., Warn HK., Washbourne CL. A new valuation school: Integrating diverse values of nature in resource and land use decisions. Ecosystem Services 2016; 22: 213-220.

Karabulut M. An examination and monitoring vegetation conditions in Turkey using NOAA AVHRR Data. Journal of Geographical Sciences 2006; 4(1): 29-42

Kayman Ö. Effect of spectral indices over land use/cover classification: Istanbul, Beylikdüzü District, land use change. Master Thesis, Istanbul University, Istanbul, 2015.

Kindu M., Schneider T., Teketay D., Knoke T. Changes of ecosystem service values in response to land use/land cover dynamics in Munessa- Shashemene landscape of the Ethiopian highlands. Sci. Total Environ.2016; 547: 137-147.

Kubiszewski I., Costanza R., Dorji L., Thoennes P., Tshering K. An initial estimate of the value of ecosystem services in Bhutan. Ecosyst. Serv.2013; 3: e11-e21.

Kumar U., Dasgupta A., Mukhopadhyay C., Ramachandra TV. Random forest algorithm with derived geographical layers for improved classification of remote sensing data. Proceedings of the Indicon 2011, Engineering Sustainable Solutions, December 16-18, pp. 1-6. Hyderabad - India,

Lam ST., Conway TM. Ecosystem services in urban land use planning policies: A case study of Ontario municipalities, Land Use Policy 2018; 77: 641-651. 
Li X., Liu L., Huang L. The international archives of the photogrammetry. Remote Sensing and Spatial Information Sciences. Volume XLII-3/W10, 2020 International Conference on Geomatics in the Big Data Era (ICGBD), 15-17 November 2019, Guilin, Guangxi, China

Li R., Dong M., Cui J., Zhang L., Cui Q., He W. Quantification of the impact of land-use changes on ecosystem services: a case study in Pingbian County. China. Environmental Monitoring and Assessment 2007; 128: 503-510.

MEA (Millennium Ecosystem Assessment). Ecosystems and human well- being: Biodiversity Synthesis. World Resources Institute, Washington, DC. 2005.

Mermer A., Yıldız H., Ünal E., Urla Ö., Aydoğdu M., Avă̆ A., Özgöz MM., Aksakal E., Dumlu S., Koç A., Şimşek U., Özaydın KA., Aydoğmuş O., Dedeoğlu F., Tuğaç MG., Torunlar H. Monitoring rangeland vegetation through satellite images (NDVI) in Eastern Anatolia Region. The 9th Field Crops Congress of Turkey, 12-15 September, 2011, Bursa.

Msofe NK., Sheng L., Li Z. Lyimo J. Impact of land use/cover change on ecosystem service values in the Kilombero Valley Floodplan, South Eastern Tanzania. Forests 2020; 11(1): 109

Na X., Zhang S., Li X., Yu H., Liu C. Improved land cover mapping using random forests combined with Landsat thematic mapper imagery and ancillary geographic data. Photogrammetric Engineering Remote Sensing 2010; 76(7): 833-840.

Osunmadewa BA., Gebrehiwot WZ., Csaplovics E., Adeofun OC. Spatio-temporal monitoring of vegetation phenology in the dry sub-humid region of Nigeria using time series of AVHRR NDVI and TAMSAT datasets. Open Geosci. 2018; 10: 1-11.

Pektezel H., Ateş M. Kapaklı ilçesi’nde (Tekirdağ) arazi kullanımı. Kapaklı, İstanbul, Babil Yayınevi 2016.

Pielke RA., Pitman A., Niyogi D., Mahmood R., McAlpine C., Hossain F., Glodewijk KK., Nair U., Betts R., Fall S., Reichstein M., Kabat P., de Noblet N. Land use/land cover changes and climate: Modelling analysis and observational evidence. Climate Change 2011; 2(6): 828-850.

Quintas-Soriano C., Castro AJ., Castro H. Impacts of land use change on ecosystem services and implications for human well-being in Spanish drylands. Land Use Policy 2016; 54: 534-548.

Roces-Díaz JV., Díaz-Varela RA., Álvarez-Álvarez P., Recondo C., Díaz-Varela, ER. A multiscale analysis of ecosystem services supply in the NW Iberian Peninsula from a functional perspective. Ecological Indicators 2014; 50: 24-34.

Rouse JW., Haas RH., Schell JA., Deering DW. Monitoring vegetation systems in the Great Plains with ERTS. Proceedings of the Third ERTS Symposium, NASA SP-351, 1973, Washington, DC, NASA, 309-317.

Sharma R., Rimal B., Baral H., Nehren U., Paudyal K., Sharma S., Rijal S., Ranpal S., Acharya RP., Alenazy AA., Kandel P. Impact of land cover change on ecosystem services in a tropical forested landscape. Resources 2019, 8: 18.

Srivastava PK., Sudhir K., Singh SK., Gupta M., Thakur JK., Mukherjee S. Modelling impact of land use change trajectories on groundwater quality using remote sensing and GIS. Environmental Engineering and Management Journal 2013; 12: 2343-2355. 
Song X., Hansen MC., Stehman SV., Potapov PV., Tyukavina A., Vermote EF., Townshend JR. Global land change from 1982 to 2016. Letter 2016; 560- 639.

TEEB. The economics of ecosystems and biodiversity: ecological and economic foundations. Earthscan, London and Washington, DC. 2010.

Tang Z., Shi C., Bi K. Impacts of land cover change and socioeconomic development on ecosystem service values. Environmental Engineering and Management Journal 2014; 13(10): 2697-2705.

Teng WL. AVHRR monitoring of U.S crops during the 1988 drought. Photogrametric Engineering and Remote Sensing 1990; 56 (8): 1143-1146.

Tokgöz G. Evaluation of the urban planning based on ecosystem services in the case of Adana- Karaisali. PhD

Thesis, Çukurova University Institute of Natural and Applied Sciences Department of Landscape Architecture, Adana, Turkey, 2018.

Tolessa T., Senbeta F., Kidane M. The impact of land use/land cover change on ecosystem services in the central highlands of Ethiopia. Ecosystem Services 2017; 23: 47-54.

Tucker CJ., Holben BN., Elgin JH., McMurtrey JE. III. Relationship of spectral data to grain yield variation. Photogrammetric Engineering and Remote Sensing 1980; 46(5): 657-666.

TUIK, Turkish Statical Institute. 2016.

Turner BL., Lambin EF., Reenberg A. The emergence of land change science for global environmental change and sustainability. Proceeding of the National Academy of Sciences of the United States of America 2007; 104: 20666-20671.

Url.1. https://www.eea.europa.eu/help/faq/what-is-corine-land-cover (Erişim Tarihi: 22.10.2021).

Url.2. https://developers.google.com/earth-engine/datasets/catalog/COPERNICUS_CORINE_V20_100m (Erişim Tarihi: 22.10.2021).

Van der Ploeg S., De Groot R., Wang Y. The TEEB valuation database: Overview of Structure, Data and Results; Foundation for Sustainable Development: Wageningen 2010; The Netherlands.

Wang Z., Wang Z., Zhang B., Lu C., Ren C. Impact of land use/land cover changes on ecosystem services in the Nenjiang River Basin, Northeast China, Ecological Processes 2015; 4: 11.

Weng Q., Lo CP. Spatial analysis of urban growth impacts on vegetative greenness with Landsat TM data. Geocarto International 2001; 16 (4): 17-25.

Wright C., Gallant A. Improved wetland remote sensing in Yellowstone National Park using classification trees to combine TM imagery and ancillary environmental data. Remote Sensing of Environment 2007; 107(4): 582-605.

Yang W., Yang L., Merchant JM. An assessment of AVHRR/NDVI-eco- climatological relations in Nebraska, U.S.A. International Journal of Remote Sensing, 1997; 18(10): 2161-2180.

Yıldız H., Mermer A., Ünal E., Akbaş F. Spatial and temporal analysis of Turkey vegetation with NDVI images. Journal of Field Crops Central Research Institute 2012; 21(2): 50-56.

Yılmaz T. Mediterranean natural vegetation. Çukurova University Faculty of Agriculture, Adana.1996.

Zhang C., Li W., Travis D. Gaps-fill of SLC-off Landsat ETM + satellite image using a geostatistical approach, International Journal of Remote Sensing 2007; 28(22): 5103-5122. 
Zhao L., Zhou GH. Strawberry image segmentation based on ISODATA algorithm. Hubei Agricultural Sciences, 2016, 55(18): 4812-4813.

Zhang X., Li S. Landscape pattern and design for the ecosystem in constructed wetland, Environmental Engineering and Management Journal, 2020; 19(9): 1459-1465. 